REVIEWS

\title{
Evaluation of evidence-based practice of catheter associated urinary tract infections prevention in a critical care setting: An integrative review
}

\author{
Michelle Henry* \\ School of Nursing, Johns Hopkins University, Baltimore, MD, United States
}

Received: September 12, 2017

DOI: $10.5430 /$ jnep.v8n7p22

\author{
Accepted: January 9, 2018 \\ Online Published: January 29, 2018
}

URL: https://doi.org/10.5430/jnep.v8n7p22

\begin{abstract}
Background and objective: An estimated 449,300 catheter-associated tract urinary infection (CAUTI) incidents affecting Americans and 13,000 CAUTI-related deaths in the United States every year. The purpose of the review was the appraisal and integration of the best evidence practice for preventing CAUTI interventions and strategies to guide safety and quality initiatives in order to improve patient care.

Methods: A total of 20 articles complied with the exclusion and inclusion criteria. The articles were studied, and the chosen articles were categorized in two areas of study: CAUTI prevention, and nurse education and knowledge improvement.

Results: The articles selected were reviewed to encompass a review on the articles offering the most applicable corresponding information involving catheter-associated urinary tract infections and competency-based education.

Conclusions: Analysis of the data from the literature search indicates the potential lack of compliance of CAUTI infection control practices is an issue for CAUTI problem. So implementing the best evidence to enforce CAUTI bundles compliance for CAUTI prevention is a key to reduce CAUTI rates.
\end{abstract}

Key Words: Catheter-associated urinary tract infections and intervention, Hospital-acquired infections, urinary tract infections, Health care-acquired infections, Urinary catheter, Indwelling urinary catheter, Nosocomial urinary infection, Bacteriuria

\section{INTRODUCTION}

Catheter-associated tract urinary infection (CAUTI) is one of the most significant patient safety problems. Each year there are 449, 334 CAUTI incidents affecting Americans and 13,000 CAUTI-related deaths in the United States. The morbidity and mortality rate of patients contracting a CAUTI is 2.8 times greater than a patient who does not contract a CAUTI ${ }^{[1]}$ It accounts for $40 \%$ of healthcare-associated infections (HAIs) and $23 \%$ of CAUTI occur in intensive care units (ICU). ${ }^{[2]}$
CAUTI also takes a major financial toll on health care costs. The Centers for Medicare \& Medicaid Services (CMS) have concluded that CAUTIs cost between $\$ 424$ and $\$ 451$ million annually. Reported estimates from individual hospitals of attributable costs of CAUTI are estimated to be between $\$ 500$ and $\$ 700$ per case. If a patient develops bacteremia secondary to CAUTI, estimates of cost per case increased between $\$ 2,500$ and $\$ 3,000 .{ }^{[3]}$ The growth rate of health care costs made it critical for government payers of health care services to study every possibility available to save health

*Correspondence: Michelle Henry; Email: Henry.SMichelle@gmail.com; Address: School of Nursing, Johns Hopkins University, Baltimore, MD, United States. 
care funds. The Congressional Budget Office (CBO) asserts that without any updates to federal law, expenditures on health care will increase from 16 percent of the gross domestic product (GPD) in 2007 to 25 percent in 2025 and 49 percent in 2082. ${ }^{[1]}$

The United States government, in an attempt to reduce health care costs, passed a number of initiatives as part of the Medicare Modernization Act of 2003 and the Deficit Reduction Act of 2005. ${ }^{[4]}$ Beginning in October 2008, the Centers for Medicare and Medicaid Services (CMS) no longer reimburses treatment for specific "reasonably preventable" hospital-acquired complications to motivate hospitals to enhance patient safety, and decrease Medicare spending. ${ }^{[4]}$ In July, 2015, the CMS announced the FY 2016 final rule, and they also finalized new regulations directing mandatory reporting by law of hospital-acquired infection data to the National Healthcare Safety Network, and CAUTI must be included as part of the monthly reports. ${ }^{[2]}$

Most recent studies emphasize CAUTI prevention to reduce CAUTI and promote patient safety. This integrative review's purpose is to synopsize the applicable literature and evidencebased practices for CAUTI prevention interventions and strategies for guiding quality and safety initiatives in order to improve quality patient care.

\section{Definitions}

The Centers for Disease Control and Prevention (CDC) defines urinary tract infections (UTIs) as an infection involving the kidneys, urethra, ureters, or bladder. Symptoms may include a burning sensation when urinating; an intense or frequent intense urge to urinate; bloody, dark, cloudy, or abnormal-smelling urine; feeling shaky or tired; and chills or fever. ${ }^{[2]}$

The National Healthcare Safety Network and CMS uses CDC definitions for identification and monitoring of CAUTI, which states that CAUTI is an UTI that develops in patients with indwelling catheters in place for over 48 hours. An indwelling catheter is specifically defined as a drainage tube inserted into the urinary bladder through the urethra, left in place, and connected to a closed collection system. As such, it excludes straight catheters, suprapubic catheters, nephrostomy tubes, ileoconduits, and condom catheters. ${ }^{[5]}$

A number of factors contribute to CAUTI, including prolonged catheterization, female gender, age over 65, inappropriate use of indwelling urinary catheters and antibiotics, bacterial entrance via the catheter-urethral interface, bacterial contamination due to manipulation of the catheter and drainage system, inadequate environment hygiene conditions and disposal of waste, inadequate use of standard and isolation precautions, poor hand hygiene, poor urinary catheter care, as these leads poor patients' outcomes and infections. ${ }^{[6,7]}$

\section{MeTHODS}

\subsection{Search strategy}

Literature searches were conducted by the author in the Cumulative Index to Nursing and Allied Health Literature (CINAHL), Embase, and PubMed databases explore interventions for preventing CAUTI in nursing practice with the goal to integrate the best evidence practice on preventing CAUTI interventions and strategies to improve patient care. The following Medical Subject Headings (MeSH) were used: catheter-associated urinary tract infections, hospital-acquired infections, urinary tract infections, health care-acquired infections, urinary catheter, indwelling urinary catheter, nosocomial urinary infection, and bacteriuria. The literature search was augmented with the terms "nursing interventions", "nursing strategies", and "quality improvement". The Boolean indicator "AND" was employed to determine articles that related to both catheter-associated urinary tract infection and interventions. All search terms were adapted to comply with the thesaurus for each respective database. The literature search did not include local unpublished reports, academic theses, and unpublished surveys.

\subsection{Eligibility criteria}

The implemented search was restricted to peer-reviewed research articles. It was further defined to include the following specific inclusion criteria: articles were published within the last five years from 2010 to 2015, were in English, have an abstract, and were restricted to adult patients (defined as being 18 years of age or older). The search did not include articles published before 2010, did not include abstracts, were not published in the English language, and included subjects less than 18 years old.

\subsection{Study quality assessment}

The author conducted a study quality assessment and reviewed the information using a two-tiered review process. The first tier of the review process was performed to ensure that the reviewed articles and studies met exclusion and inclusion criteria. A second-tier review was performed to finalize the evaluation of each individual article in the study assessment in accordance with standard strength and quality measures specified.

The study quality assessment was analyzed using the Johns Hopkins University (JHU) Research and Non-Research Evidence Appraisal Tool (Appendix E\&F). ${ }^{[8]}$ The tool was employed to classify and assess the quality and level of the 
evidence that was obtained from the search. The level of the research evidence was evaluated as Level I (experimental study and meta-analysis of randomized controlled trials [RCTs]), Level II (quasi-experimental study), or Level III (qualitative study, meta-synthesis, or nonexperimental study).

\section{RESULTS}

\subsection{Search results}

A total of 680 relevant articles were initially identified as a result of the literature search. After filtering through the screening criteria, the number of articles was reduced to a total of 62 articles in full-text, of those, 42 studies were not included because they were not relevant to the acute clinical practice setting or other suitable criteria. The remaining 20 studies satisfied the inclusion and exclusion criteria. A synopsis of the search strategy used is shown in Figure 1.

\subsection{Quality of the studies}

Assessment of the articles determined that a majority of the articles (15 out of 20) searched were categorized as level III-a non-experimental studies or qualitative studies. Two additional articles were categorized as level I since they covered experimental studies or meta-analysis of randomized controlled trials (RCTs). One article was an expert opinion and was categorized to be level IV, and the final two articles consisted of clinical guidelines recommended by experts, and were categorized as level V. Rating of the quality of evidence was performed using the JHU Evidence Appraisal Tool with evidence rated using the following scale: $\mathrm{A}=$ high quality, $\mathrm{B}$ = good quality and $\mathrm{C}=$ low quality data or major flaws.

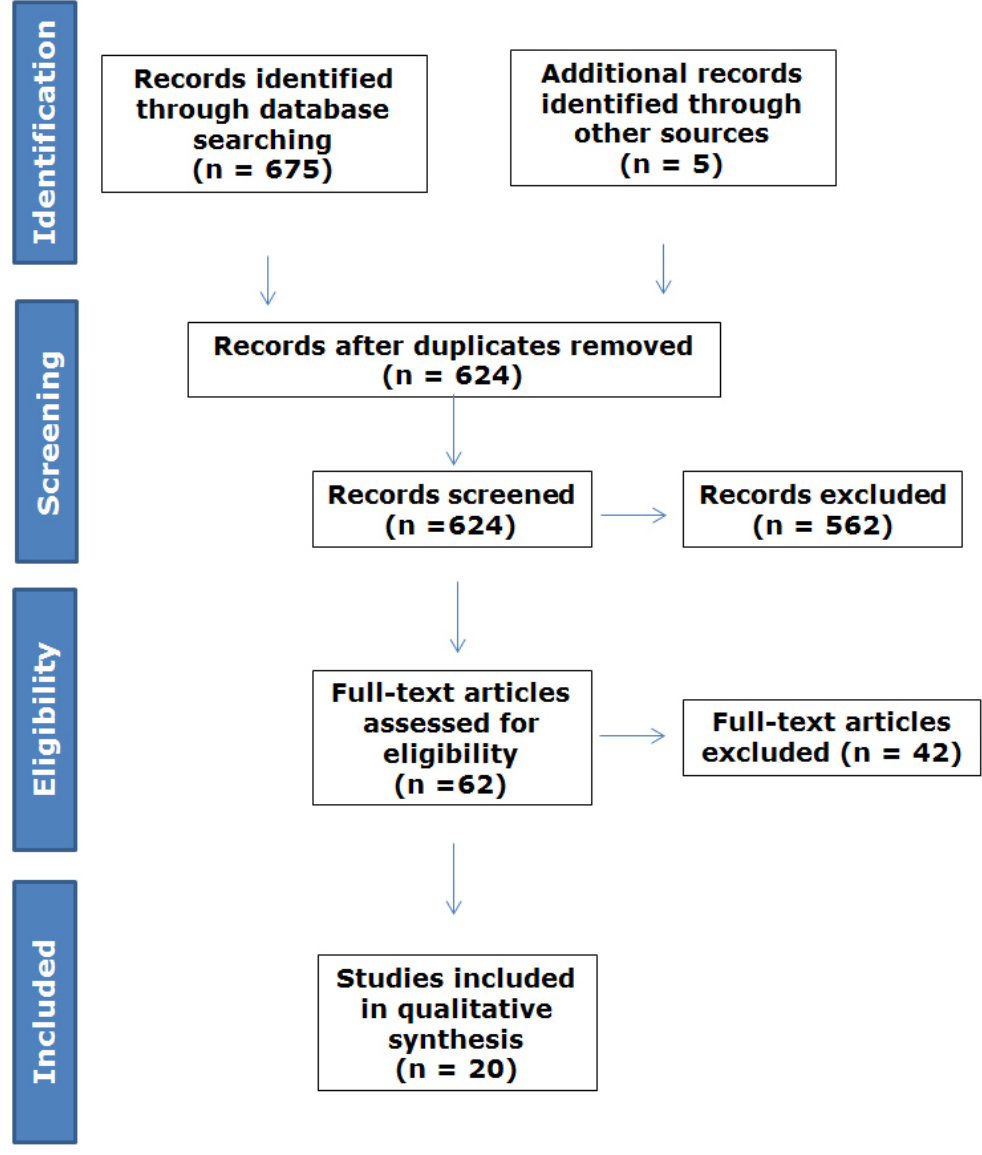

Figure 1. Prisma flow diagram. From: Moher D. liberati A, Tetziaff, AltmanDG, The PRISMA group (2009). Preferred reportingitems for Systematic Reviews and Meta-Analysis: The PRISMA Statement. Plos Med. (6):e1000097.

Eleven out of 20 articles reviewed were graded "high" quality or "A" level evidence. "High" quality data is defined as data considered to be consistent with generalizable results by the Evidence Appraisal Tool. The collected data was the result of a satisfactory sample size within the context of the study design, had acceptable controls, elicited decisive conclusions, and delivered reliable recommendations based on all-inclusive literature reviews that include comprehensive referral to scientific evidence.

The final nine articles obtained from the literature search 
were "good" quality or "B" level evidence. "Good" quality data is defined as data that is acceptably consistent and obtained from an adequate sample size for the study design consistent with generalizable results by the Evidence Appraisal Tool. Some control in the study resulted from the data, and came to moderately conclusive conclusions. Collected data gave relatively reliable recommendations grounded in a fairly thorough literature review which contained several referrals to scientific evidence. The result of the evidence evaluation is listed below:

- 1 article was a Level I, high quality RCT study, classified as I A in the JHU evidence evaluation tool.

- 10 articles were Level III, high-quality nonexperimental studies; or qualitative studies, classified as III A in the JHU evidence evaluation tool.

- 1 article was a Level I, good quality RCT study, classified as I B in the JHU evidence evaluation tool.
- 5 articles were Level III, good-quality nonexperimental studies; or qualitative studies, classified as III B in the JHU evidence evaluation tool.

- 1 article was a Level 4 good-quality opinion of a respected authority classified as IV B in the JHU evidence evaluation tool

- 2 articles were Level 5, good-quality evidence obtained from literature reviews; quality improvement classified as V B in the JHU evidence evaluation tool

\subsection{Aggregate data synthesis}

Fifteen studies were performed in the United States (75\%), one in Argentina, one in Egypt, one in Greece, one in the Philippines and two in China.

The selected articles focus on the following information found in Table 1.

Table 1. Johns Hopkins nursing evidence-based practice synthesis and recommendations tool

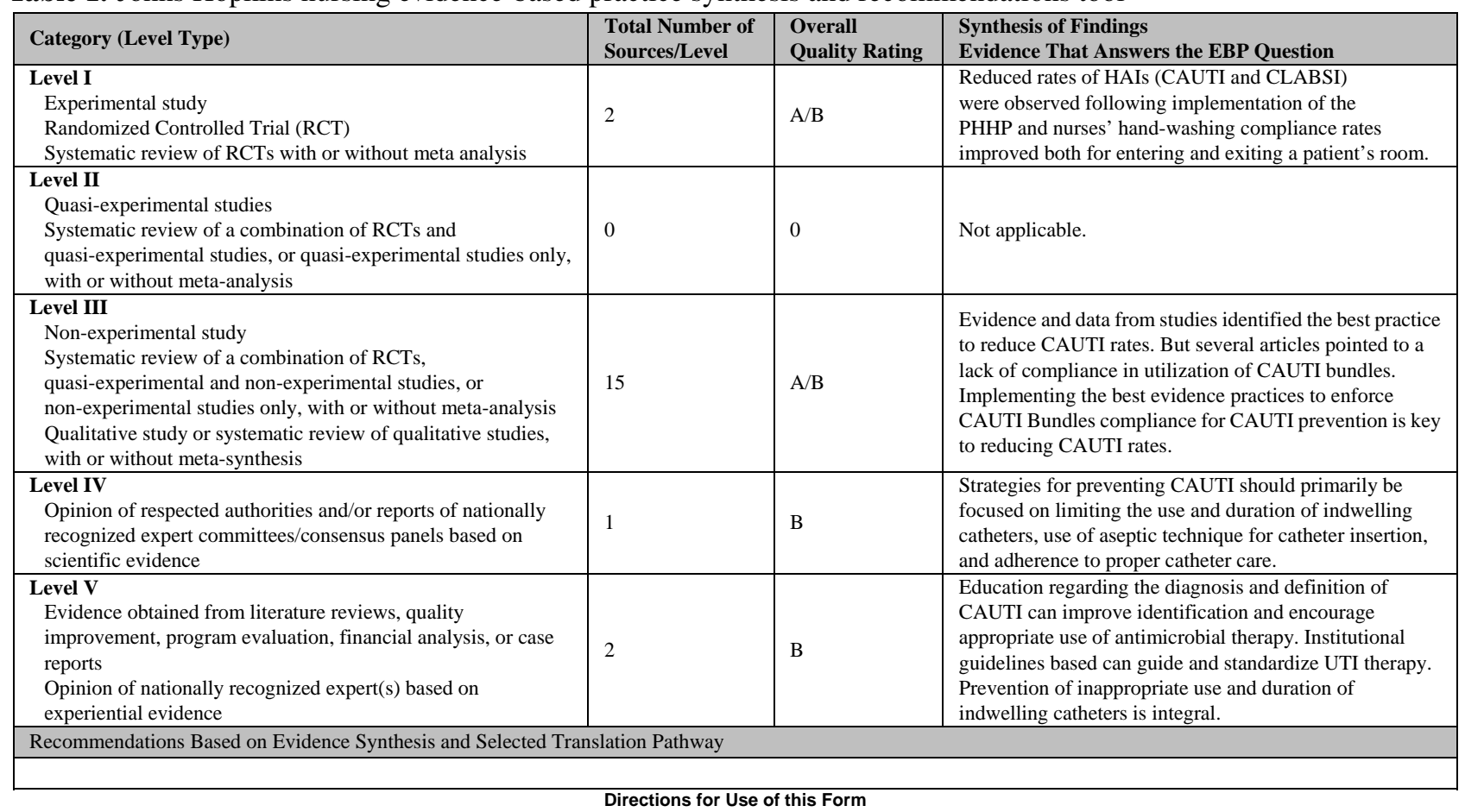

Purpose: This form is used to compile the results of the evidence appraisal to answer the EBP question. The pertinent findings for each level of evidence are synthesized and a quality rating is assigned to each level.

Total Number of Sources per Level: Record the number of sources of evidence for each level.

Overall Quality Rating: Summarize the quality of evidence for each level; use ranges as appropriate, for example (A/B).

Synthesis of Findings: Evidence That Answers the EBP Question

- Include only findings from evidence of A or B quality.

- Include only statements that directly answer the EBP question.

- Summarize findings within each level of evidence.

- Record article number(s) from individual evidence summary in parentheses next to each statement so it is easy to identify the source of the finding.

Develop Recommendations Based on Evidence Synthesis and the Selected Translation Pathway: Review the synthesis of findings and determine which of the following four pathways to translation represents the overall strength of the evidence:

- Compelling evidence: solid indication for a practice change

- Good and consistent evidence: consider pilot of change or further investigation

- Good but conflicting evidence: no indication for practice change, consider further investigation for new evidence or develop a research study

- Little or no evidence: no indication for practice change, consider further investigation for new evidence or develop a research study 
Evidence-based intervention programs for the deterrence and identification of CAUTI Throughout the review of the literature, several kinds of interventions were considered for the prevention of CAUTI and improving patient safety and quality care. Catheter-associated urinary tract infection prevention interventions played a crucial role for early identification of patients who are at risk of developing CAUTI and staff knowledge of CAUTI prevention was critical to evaluations, mitigation of risk factors, and provision of preventative care. CAUTI prevention guidelines are essential evidence-based tools necessary for influencing the patient care process in health care facilities.

The data gathered in Tables 2 and 3 provides a summarized description of the evidence collected during the data search.

\section{Discussion}

The evidence and data from the analyzed studies identified several of the best practices to reduce CAUTI rates. A number of interventions and practices were identified for CAUTI prevention. Those practices and interventions include the use of urine cultures, hand washing, reducing the number of days for indwelling catheters, and the use of CAUTI prevention bundles. Most hospitals have infection control teams composed of physicians and ICPs with infection control experience to help with the development and implementation of CAUTI prevention practices. These teams usually consist of at least one physician and several infection control nurses. Nurses on the infection control team have experience and training in infection control and work as full time members of the team. Their responsibility is to collect patient information, and once a CAUTI is suspected, it is their job to report it to the physician for an immediate diagnosis. ${ }^{[9]}$

\subsection{Use of urine samples}

Several studies advocated the use of urine samples as a means of identifying CAUTI for patients with fevers. In those studies, lower CAUTI rates were related to the use of urine cultures for patients with suspected urinary tract infections or sepsis or in the study hospitals. High CAUTI rates for hospitals participating in the studies were attributed to the fact that most limited-resource countries do not have laws mandating hospital infection control programs or hospital accreditation. ${ }^{[10]}$ While urine cultures for patients with fevers helped identify potential CAUTI incidences, most patients with CAUTIs are eventually found to have alternative explanations for fever. ${ }^{[11]}$

\subsection{Use of patient hand hygiene protocols}

Studies also recommended the use of patient hand hygiene protocols (PHHP) as a CAUTI intervention. A reduction in CAUTI rates was observed following the introduction of the PHHP and nurses' hand-washing compliance rates improved both for entering and exiting a patient's room. ${ }^{[12]}$ In one study, CAUTI results were determined by comparing monthly means before and during utilization of a PHHP. The mean monthly CAUTI rate was reduced from 9.1 incidents to 5.6 incidents per 1,000 catheter days, and indwelling catheter device utilization days were reduced from 5,190 days to 4,992 days. $^{[13]}$

\subsection{Limiting the use and duration of indwelling catheters}

Several studies recommended strategies for preventing CAUTI that focused on limiting the use and duration of indwelling catheters, use of aseptic technique for catheter insertion, and adherence to proper catheter care. It has been recommended not to use the indwelling catheters unless absolutely necessary and alternatives to indwelling catheterization should be considered. ${ }^{[2]}$ Before introducing a nurse-driven catheter removal protocol in a particular study, indwelling urinary catheter usage was at $37.6 \%$, with a mean dwell time was 3.35 days, and a CAUTI rate was $0.77 \%$. Once the removal protocol was introduced, catheter usage was reduced to $27.7 \%$, with a mean dwell time of 3.46 days, and a CAUTI rate of $0.35 \% .{ }^{[14]}$ In another study, use of indwelling urinary catheters were reduced facility-wide by $50 \%$ and infections attributed to their use fell by a statistically significant $3.3 \%$ per month over a 36-month period with our multifaceted program. The critical component of this initiative was the nurse-directed catheter removal protocol. It not only reduced urinary catheter utilization rates and ultimately CAUTIs, but it also resulted in a culture change for the facility, enhancing teamwork and ownership among the disciplines involved in the process. ${ }^{[15]}$ These studies indicate that early removal of the catheter using a reminder or nurse-initiated removal protocol appears to be warranted. ${ }^{[2]}$

\subsection{Antibiotic prophylaxis}

Education regarding the diagnosis and definition of CAUTI can improve identification and encourage appropriate use of antimicrobial therapy. Institutional guidelines can guide and standardize urinary tract infection prevention and treatment. Efforts focusing on reducing unsuitable antimicrobial use for CAUTI should be part of an all-inclusive antimicrobial stewardship program. ${ }^{[16,17]}$ Twenty-six trials that considered 12,422 hospitalized adults in 25 parallel group trials, and 27,878 adults in one large cluster-randomized cross-over trial were involved in a systematic review for CAUTI prevention. 
Table 2. Individual evidence summary, part 1

\begin{tabular}{|c|c|c|c|c|c|c|}
\hline Article \# & $\begin{array}{l}\text { Author \& } \\
\text { Date }\end{array}$ & Evidence Type & $\begin{array}{l}\text { Sample, Sample } \\
\text { Size, \& Setting }\end{array}$ & $\begin{array}{l}\text { Study findings that help } \\
\text { answer the EBP question }\end{array}$ & Limitations & $\begin{array}{l}\text { Evidence Level } \\
\text { \& Quality }\end{array}$ \\
\hline 1 & $\begin{array}{l}\text { Al-Qas Hanna } \\
\text { F. (2013) }\end{array}$ & Qualitative Study & $\begin{array}{l}\text { 804-bed, acute } \\
\text { teaching hospital, } \\
\text { in Detroit, MI. }\end{array}$ & $\begin{array}{l}\text { Efforts that focus on reducing } \\
\text { inappropriate antimicrobial } \\
\text { use for asymptomatic } \\
\text { bacteriuria to be part of a } \\
\text { comprehensive antimicrobial } \\
\text { stewardship program }\end{array}$ & $\begin{array}{l}\text { It is a retrospective } \\
\text { evaluation of patient } \\
\text { records and is } \\
\text { susceptible to } \\
\text { documentation by } \\
\text { healthcare providers. }\end{array}$ & III A \\
\hline 2 & Hu B. (2013) & $\begin{array}{l}\text { Qualitative Cohort } \\
\text { Study }\end{array}$ & $\begin{array}{l}\text { Cohort study in } 7 \\
\text { ICUs in } 4 \text { hospitals }\end{array}$ & $\begin{array}{l}\text { (Global data) Across the whole } \\
\text { study, } 5.4 \% \text { of the patients } \\
\text { admitted died. Mortality was } \\
47 \% \text { in patients with CAUTI. }\end{array}$ & $\begin{array}{l}\text { Study has } \\
\text { methodological } \\
\text { limitations. } \\
\text { A change in ICU } \\
\text { practices is needed. }\end{array}$ & III B \\
\hline 3 & $\begin{array}{l}\text { Navoa-Ng J. } \\
\text { (2011) }\end{array}$ & $\begin{array}{l}\text { Qualitative Cohort } \\
\text { Study }\end{array}$ & $\begin{array}{l}\text { This study was } \\
\text { carried out in } 6 \\
\text { adult ICUs }\end{array}$ & $\begin{array}{l}\text { (GLOBAL) The CAUTI rate } \\
\text { was } 4.16 \text { per 1,000 urinary } \\
\text { catheter-days ( } 95 \% \text { CI, } \\
\text { 3.0-5.7) in the AICUs and } 0.0 \\
\text { in the PICU. }\end{array}$ & $\begin{array}{l}\text { Data might not } \\
\text { adequately reflect the } \\
\text { situation throughout the } \\
\text { Philippines. }\end{array}$ & III B \\
\hline 4 & $\begin{array}{l}\text { Rosenthal V. } \\
\text { (2014) }\end{array}$ & Non-Experimental & $\begin{array}{l}\text { Multicenter } \\
\text { surveillance study } \\
\text { in } 503 \text { intensive } \\
\text { care units (ICUs) in } \\
43 \text { countries. }\end{array}$ & $\begin{array}{l}\text { (GLOBAL) The overall } \\
\text { CAUTI rate per 1,000 catheter } \\
\text { days was } 5.30 \text { ( } 95 \% \text { CI, } \\
5.2-5.4) \text { in the adult and } \\
\text { pediatric ICUs. }\end{array}$ & $\begin{array}{l}\text { The mean length of } \\
\text { participation of hospitals } \\
\text { in the INICC program } \\
\text { SD is } 19.5 \pm 17.7 \\
\text { months (range, } 1-72 \\
\text { months) }\end{array}$ & III B \\
\hline 5 & $\begin{array}{l}\text { Davis K. } \\
\text { (2014) }\end{array}$ & $\begin{array}{l}\text { Observational } \\
\text { study using QI }\end{array}$ & $\begin{array}{l}2 \text { observational } \\
\text { studies in a } \\
500 \text {-bed hospital } \\
\text { where 40\% of } \\
\text { beds in ICUs }\end{array}$ & $\begin{array}{l}\text { (National) In adults, the } \\
\text { urinary tract is the most } \\
\text { common site of infection and } \\
\text { accounts for } \sim 40 \% \text { of all } \\
\text { reported health care- } \\
\text { associated infections, the } \\
\text { majority of which are CAUTIs }\end{array}$ & $\begin{array}{l}\text { Unable to determine } \\
\text { whether the } \\
\text { interventions caused the } \\
\text { reduction in CAUTI }\end{array}$ & IV B \\
\hline 6 & $\begin{array}{l}\text { Apostopoulou } \\
\text { E. (2015) }\end{array}$ & $\begin{array}{l}\text { Prospective } \\
\text { Observational } \\
\text { study }\end{array}$ & $\begin{array}{l}2 \text { ICUs from } \\
\text { January to } \\
\text { December } 2010\end{array}$ & $\begin{array}{l}\text { A total of } 234 \text { patients with } \\
4,551 \text { patient days were } \\
\text { hospitalized in the ICU. The } \\
\text { incidence of CAUTI was } 7.7 \% \\
\text { and the incidence density was } \\
4.09 \text { cases } 1,000 \text { urinary } \\
\text { catheter-days. }\end{array}$ & $\begin{array}{l}\text { Study did not include a } \\
\text { sufficiently large } \\
\text { number of patients. } \\
\text { Second, this study was } \\
\text { performed in two units }\end{array}$ & III A \\
\hline 7 & $\begin{array}{l}\text { Fuchs M. } \\
\text { (2011) }\end{array}$ & $\begin{array}{l}\text { Non-Experimental } \\
\text { descriptive study }\end{array}$ & $\begin{array}{l}\text { A total of } 408 \\
\text { providers from the } \\
5 \text { adult ICUs }\end{array}$ & $\begin{array}{l}\text { Overall the provider survey } \\
\text { indicated relevance to practice } \\
\text { ( } 83.5 \% \text { ), satisfaction with the } \\
\text { implementation (64\%), ease of } \\
\text { use (68\%), and compliance } \\
\text { with the daily checklist (90\%). }\end{array}$ & $\begin{array}{l}\text { Generalizability of } \\
\text { results may be limited to } \\
\text { hospitals of similar size } \\
\text { and type. }\end{array}$ & III B \\
\hline 8 & $\begin{array}{l}\text { Chenoweth, C. } \\
\text { (2011) }\end{array}$ & Expert opinion & Hospital & $\begin{array}{l}\text { Adherence to general infection } \\
\text { control principles (e.g., hand } \\
\text { hygiene, surveillance and } \\
\text { feedback, aseptic insertion, } \\
\text { proper maintenance, } \\
\text { education) is important. }\end{array}$ & $\begin{array}{l}\text { Avoid use of indwelling } \\
\text { urinary catheters } \\
\text { placement only for } \\
\text { appropriate indications. }\end{array}$ & V B \\
\hline 9 & Krein S. (2011) & Non-experimental & $\begin{array}{l}\text { VA medical centers } \\
\text { with surgical care } \\
\text { operating beds ( } \mathrm{n}= \\
\text { 119). }\end{array}$ & $\begin{array}{l}\text { Given a nearly } 70 \% \text { response } \\
\text { in the sample in both years we } \\
\text { believe these results provide a } \\
\text { reasonable estimate of the use } \\
\text { of infection prevention } \\
\text { practices by U.S. non-federal } \\
\text { hospitals. }\end{array}$ & $\begin{array}{l}\text { Non-response bias is a } \\
\text { potential issue. The } \\
\text { overall response rate } \\
\text { was approximately } 70 \% \\
\text { in both years. }\end{array}$ & III B \\
\hline 10 & $\begin{array}{l}\text { Trautner B. } \\
\text { (2011) }\end{array}$ & Experimental & $\begin{array}{l}\text { The intervention } \\
\text { and the control } \\
\text { sites are two VA } \\
\text { hospitals. }\end{array}$ & $\begin{array}{l}\text { Study had } 80 \% \text { power to detect } \\
\text { a } 25 \% \text { reduction in percentage } \\
\text { of patients screened, even if } \\
\text { the percentage of screened } \\
\text { patients is as low as } 10 \% \text {. }\end{array}$ & $\begin{array}{l}\text { Our intervention is } \\
\text { tightly focused on a } \\
\text { specific aspect of } \\
\text { poor-quality care that } \\
\text { has been observed. }\end{array}$ & I B \\
\hline
\end{tabular}


Table 3. Individual evidence summary, part 2

\begin{tabular}{|c|c|c|c|c|c|c|}
\hline Article \# & $\begin{array}{l}\text { Author \& } \\
\text { Date }\end{array}$ & Evidence Type & $\begin{array}{l}\text { Sample, Sample Size, \& } \\
\text { Setting }\end{array}$ & $\begin{array}{l}\text { Study findings that help answer } \\
\text { the EBP question }\end{array}$ & Limitations & $\begin{array}{l}\text { Evidence Level } \\
\text { \& Quality }\end{array}$ \\
\hline 11 & $\begin{array}{l}\text { Mori C. } \\
\text { (2014) }\end{array}$ & Non-experimental & $\begin{array}{l}\text { Study conducted in a } \\
\text { 150-bed community } \\
\text { hospital in northern } \\
\text { United States. }\end{array}$ & $\begin{array}{l}\text { A continued need to reinforce the } \\
\text { importance of securing the drainage } \\
\text { tubing to the bed was supported by } \\
\text { the noncompliance rate of } 100 \% \text {. }\end{array}$ & $\begin{array}{l}\text { Lack of documentation } \\
\text { of acute vs. chronic } \\
\text { indwelling catheters, } \\
\text { chronic catheters not } \\
\text { excluded in the study. }\end{array}$ & III A \\
\hline 12 & $\begin{array}{l}\text { Medding J. } \\
\text { (2012) }\end{array}$ & Non-experimental & $\begin{array}{l}\text { Adult patients discharged } \\
\text { from acute care hospital } \\
\text { in Michigan in } 2007 \text { \& } \\
2009\end{array}$ & $\begin{array}{l}\text { (National) The rate for diagnosis } \\
\text { ranged from } 5.2 \% \text { to } 17.1 \% \text { (mean, } \\
10.0 \% \text { [CI, } 9.5 \% \text { to } 10.5 \% \text { ]) in } 2007 \\
\text { and } 5.0 \% \text { to } 20.2 \% \text { (mean, } 10.3 \% \\
\text { [CI, } 9.8 \% \text { to } 10.9 \% \text { ]) of discharges } \\
\text { in } 2009 \text {. }\end{array}$ & $\begin{array}{l}\text { Because many factors } \\
\text { affect infection rates, } \\
\text { the study results cannot } \\
\text { be solely attributed to } \\
\text { the intervention. }\end{array}$ & III A \\
\hline 13 & $\begin{array}{l}\text { Fox C. } \\
(2015)\end{array}$ & Experimental & $\begin{array}{l}\text { 27-bed adult cardio } \\
\text { medical ICU at Mission } \\
\text { Hosp in Mission Viejo, } \\
\text { CA }\end{array}$ & $\begin{array}{l}\text { (National) CAUTIs were measured } \\
\text { and reported by using the CDC’s } \\
\text { definition: The mean monthly } \\
\text { CAUTI rate decreased from } 9.1 \text { to } \\
5.6 \text { per } 1,000 \text { catheter days. }\end{array}$ & $\begin{array}{l}\text { Limitation of a low } \\
\text { statistical power shows } \\
\text { the implementation of } \\
\text { closed circuit drainage } \\
\text { system of the study. }\end{array}$ & I A \\
\hline 14 & $\begin{array}{l}\text { Izzo I. } \\
(2015)\end{array}$ & Non-experimental & $\begin{array}{l}\text { Patients who had a } \\
\text { urinary catheter applied } \\
\text { during stay in a ward. }\end{array}$ & $\begin{array}{l}\text { Elevated percentage of CAUTI: } \\
\text { infection over } 18 \text { patients (incidence } \\
33 \% \text {, rate } 43.4 / 1,000 \text { days/catheter). }\end{array}$ & $\begin{array}{l}\text { Performed in a single } \\
\text { tertiary-care hospital } \\
\text { with multiple ICU } \\
\text { populations, which may } \\
\text { not represent other } \\
\text { settings. }\end{array}$ & III B \\
\hline 15 & $\begin{array}{l}\text { Tedja R. } \\
\text { (2015) }\end{array}$ & Cohort Study & $\begin{array}{l}\text { Mayo Clinic is a } \\
\text { 1,200-bed hospital with } \\
158 \text { adult intensive care } \\
\text { beds. }\end{array}$ & $\begin{array}{l}\text { The median ICU length of stay for } \\
\text { the patients with CAUTI was } 10 \\
\text { days (interquartile range: 6-16 days). } \\
\text { In-hospital all-cause mortality was } \\
28 \% \text {. }\end{array}$ & $\begin{array}{l}\text { The limited evidence } \\
\text { indicated that receiving } \\
\text { prophylactic antibiotics } \\
\text { reduced the rate of } \\
\text { bacteriuria. }\end{array}$ & III B \\
\hline 16 & $\begin{array}{l}\text { Lusardi G. } \\
\text { (2013) }\end{array}$ & $\begin{array}{l}\text { Systematic } \\
\text { Review }\end{array}$ & $\begin{array}{l}\text { All adults requiring } \\
\text { short-term urinary } \\
\text { urethral and supra pubic } \\
\text { catheterize }\end{array}$ & $\begin{array}{l}\text { Six parallel-group randomized } \\
\text { controlled trials with } 789 \\
\text { participants met the inclusion } \\
\text { criteria. All six trials compared } \\
\text { antibiotic prophylaxis versus no } \\
\text { prophylaxis. }\end{array}$ & $\begin{array}{l}\text { Studies presented a low } \\
\text { to unclear risk of bias } \\
\text { with similar } \\
\text { interventions and } \\
\text { measured outcomes. }\end{array}$ & III A \\
\hline 17 & $\begin{array}{l}\text { Lam T. } \\
(2014)\end{array}$ & $\begin{array}{l}\text { Systematic } \\
\text { Review }\end{array}$ & NA & $\begin{array}{l}\text { Twenty-six trials were included in } \\
\text { systematic review involving } 12,422 \\
\text { hospitalized adults in } 25 \text { parallel } \\
\text { group trials, and } 27,878 \text { adults in one } \\
\text { large cluster- randomized cross-over } \\
\text { trial. }\end{array}$ & $\begin{array}{l}\text { These higher DA-HAI } \\
\text { rates may reflect the } \\
\text { typical ICU situation in } \\
\text { limited-resource } \\
\text { countries as a whole. }\end{array}$ & III A \\
\hline 18 & $\begin{array}{l}\text { Tao L. } \\
\text { (2011) }\end{array}$ & Non-experimental & $\begin{array}{l}\text { Study was performed in } \\
398 \text { ICUs of } 70 \text { hospitals, } \\
\text { from } 2004 \text { to } 2009 .\end{array}$ & $\begin{array}{l}\text { During the } 5 \text { years and } 4 \text { months of } \\
\text { the study, } 391,527 \text { patients } \\
\text { hospitalized in an ICU for an } \\
\text { aggregate of 3,245,244 days } \\
\text { acquired 20,866 DA-HAIs, an } \\
\text { overall rate of 5.3\% ( } 95 \% \text { CI } 5.3- \\
\text { 5.4) of DA-HAIs and } 6.4 \text { ( } 95 \% \text { CI } \\
\text { 6.3-6.5) DA-HAIs per 1,000 } \\
\text { ICU-days. }\end{array}$ & $\begin{array}{l}\text { Limitation of a low } \\
\text { statistical power shows } \\
\text { the implementation of } \\
\text { closed circuit drainage } \\
\text { system in present study. }\end{array}$ & III A \\
\hline 19 & $\begin{array}{l}\text { Kholy, A. } \\
\text { (2012) }\end{array}$ & Non-experiment & $\begin{array}{l}12 \text { hospitals have a total } \\
\text { of approximately 5,000 } \\
\text { beds and } 500 \text { ICU beds. }\end{array}$ & $\begin{array}{l}\text { During the study period (March } \\
2009 \text { to May 2010), prospective } \\
\text { surveillance data from } 5 \text { ICUs was } \\
\text { reported for } 1,101 \text { patients admitted } \\
\text { for a total of } 10,869 \text { days. CAUTI } \\
\text { rates were generally low (2.9/1,000 } \\
\text { catheter-days). Excess mortality for } \\
\text { patients with CAUTI was } 47.9 \% \text {. }\end{array}$ & $\begin{array}{l}\text { Data does not reflect the } \\
\text { burden of HAIs in all } \\
\text { ICUs in the CUH } \\
\text { complex or in ICUs } \\
\text { throughout Egypt. }\end{array}$ & III A \\
\hline 20 & $\begin{array}{l}\text { Ramanthan } \\
\text { R. (2014) }\end{array}$ & Non-experiment & Hospitals & $\begin{array}{l}\text { Urinary tract infections (UTI) } \\
\text { account for up to } 40 \% \text { of all health } \\
\text { care-acquired infections. Nearly } \\
80 \% \text { of all UTI occur in patients with } \\
\text { short-term urinary catheters and are } \\
\text { tracked as CAUTI by regulatory } \\
\text { agencies. }\end{array}$ & $\begin{array}{l}\text { Limitation of a low } \\
\text { statistical power shows } \\
\text { the implementation of } \\
\text { the closed circuit } \\
\text { drainage system of the } \\
\text { present study. }\end{array}$ & V B \\
\hline
\end{tabular}


The evidence from trials determined found that while antiseptic-coated catheters reduced the number of bacteria in the urine, they did not reduce the number of urinary tract infections caused by the presence of the catheter. Catheters coated with antimicrobials designed to stop the growth or eliminate bacteria may reduce bacterial presence in urine as well as reducing the number of people having urinary tract infections resulting from the use of indwelling catheters. ${ }^{[18]}$

\subsection{Use of prevention bundles}

Several studies found that implementing the best evidence practices for the development of CAUTI protocols and enforcement of CAUTI bundle compliance for CAUTI prevention is essential to reducing CAUTI rates. There have been many studies conducted in the United States in which the reported incidence of CAUTI can be reduced by as much as $30 \%$ through the use of multidimensional approaches, including the use of CAUTI bundle interventions. ${ }^{[19,20]}$ In one study, the introduction of a CAUTI prevention bundle was attributed with a $50 \%$ reduction in the mean monthly CAUTI rate in a hospital from 5.41 to 2.49 per 1000 catheterdays. ${ }^{[21]}$ The inclusion of electronic checklists and reminders also helps in the reduction of infections as part of CAUTI bundles. $^{[2]}$

Finally, CAUTI bundle development and implementation must have buy-in from the hospital staff for them to be effective. One of the most significant problems in several studies pointed to a lack of compliance in utilization of CAUTI bundles. ${ }^{[22]}$

\subsection{Strengths}

The variety of interventions developed was mostly based on CDC guidelines, and their successes provided the most meaningful evidence strength. The studies looked at hand washing, education programs for staffs, nurse-driven protocols, CAUTI prevention checklists, CAUTI bundling, and limiting the time allowed for the use of indwelling catheters. All interventions in the studies had some success, with combinations of intervention type showing greater promise.

A majority of the studies were done for the purpose of reducing indwelling catheterization and the duration of catheterization.

The duration of a number of the studies was long enough to allow researchers to gather statistically significant results. 6 of studies were two years to four years in length, allowing for a significant number of cases to be studied and to ensure an intervention was viable in the longer term.

\subsection{Weaknesses}

Only two studies were conducted as types of randomized control trials (RCTs) study comparing one intervention and control groups to determine the studies' result. $90 \%$ of the studies were non-experimental. A number of studies were limited in size and focused specifically on small populations.

\subsection{Limitations}

First of all, some of the studies lack of statistical data to support in CAUTI reduction on individual group or whole sample population to approve the study power and the significance. Second, some of studies did not provide intervention duration of study to allow replication of results. Finally, studies were only performed in a limited number of sample populations, and population demographics were seldom discussed for analysis in most studies.

\subsection{Future research}

CAUTI has become a worldwide health liability. The assessment of evidence- based practices for preventing CAUTI and the translation of research into practice (TRIP) is a significant factor for curtailing incidence levels of health care organizations. A majority of the studies were done for the purpose of reducing indwelling catheterization and the duration of catheterization. Increased focus of future research should be placed on reducing the need for indwelling catheterization or duration of catheterization in Intensive Care Units, since these units make greater use of indwelling catheterization and face a greater risk of CAUTI infection in patients. Future studies should also be expanded to consider alternatives to indwelling catheters.

\section{Conclusion}

Analysis of the literature has shown that numerous CAUTI interventions and strategies have significantly decreased the CAUTI occurrences. Challenges continue to remain for health providers and healthcare organizations in determining the applicability of researched interventions for their patients and the translation of the best evidence into practice. Preventing CAUTI incidents will lead to efficient, safe, and high-quality patient care, ultimately reducing the economic consequences on patients, hospitals and healthcare organizations.

\section{ACKNOWLEDGEMENTS}

I would like to acknowledge Johns Hopkins University School of Nursing in supporting this work.

\section{Conflicts of InTEREST Disclosure}

No conflicts of interest are related to this review. 


\section{REFERENCES}

[1] Center for Disease Control and Prevention. Urinary Tract Infection (Catheter-Associated Urinary Tract Infection [CAUTI] and Non-Catheter-Associated Urinary Tract Infection [UTI]) and Other Urinary System Infection [USI]) Events. 2015. Available from: http://www.cdc.gov/nhsn/pdfs/pscManual/7pscCA UTIcurrent.pdf

[2] Chenoweth C, Saint S. Urinary tract infections. Infect Dis Clin North Am. 2011 Mar; 25(1): 103-15. Epub 2010 Dec 18. Review. PMid: 21315996 https : //doi.org/10.1016/j.idc.2010.11.005

[3] How-to Guide: Prevent Catheter-Associated Urinary Tract Infections. Cambridge, MA: Institute for Healthcare Improvement; 2011. Available from: https://www.alliance4ptsafety.org/IHAM APS/media/media/HEN/ihihowtoguidepreventcauti.pdf

[4] Association for Professionals in Infection Control and Epidemiology (APIC). Guide to the Elimination of Catheter-Associated Urinary Tract Infections (CAUTIs). 2008. Available from: http: //www . ap ic.org/Resource_/EliminationGuideForm/c0790db8-2ac a-4179-a7ae-676c27592de2/File/APIC-CAUTI-Guide.pdf

[5] Lobdell K, Stamou S, Sanchez J. Hospital-acquired Infections. Surgical Clinics of North America. 2012; 92(1): 65-77. PMid:22269261 https://doi.org/10.1016/j.suc.2011.11.003

[6] Ramanathan R, Duane T. Urinary Tract Infections in Surgical Patients. Surg Clin North Am. 2014 Dec; 94(6): 1351-68. PMid: 25440128 https://doi.org/10.1016/j.suc.2014.08.007

[7] El-Kholy A, Saied T, Gaber M, et al. Device-Associated Nosocomial Infection Rates in Intensive Care Units at Cairo University Hospitals: First Step Toward Initiating Surveillance Programs in a Resource-Limited Country. American Journal of Infection Control. 2012; 40(6): e216-e220. PMid:22418610 https ://doi .org/10.1 016/j.ajic.2011.12.010

[8] Johns Hopkins University (JHU). Johns Hopkins Nursing Evidence-Based Practice Model (Appendix E\&F). 2016. Available from: http://www.hopkinsmedicine.org/evidence-b ased-practice/jhn_ebp.html

[9] Tao L, Hu B, Rosenthal VD, et al. Device-associated infection rates in 398 intensive care units in Shanghai, China: International Nosocomial Infection Control Consortium (INICC) findings. International Journal of Infectious Diseases. 2011; 15(11): e774-e780. PMid:21846591 https://doi.org/10.1016/j.ijid.2011.06 .009

[10] Hu B, Tao L, Rosenthal VD, et al. Device-associated infection rates, device use, length of stay, and mortality in intensive care units of 4 Chinese hospitals: International Nosocomial Control Consortium findings. American Journal of Infection Control. 2014; 41(4): $301-$ 306. PMid:23040491 https://doi.org/10.1016/j.ajic. 201 2.03 .037
[11] Tedja R, Wentink J, O’Horo JC, et al. Catheter-associated urinary tract infections in intensive care unit patients. Infection Control \& Hospital Epidemiology. 2015; 36(11): 1330-1334. PMid:26190686 https://doi.org/10.1017/ice.2015.172

[12] Meddings J, Reichert H, Rogers M, et al. Effect of Nonpayment for Hospital-Acquired, Catheter-Associated Urinary Tract Infection: A Statewide Analysis. Annals of Internal Medicine. 2012; 157(5): 305-312. https://doi .org/10.7326/0003-4819-157-5-201 209040-00003

[13] Fox C, Wavra T, Drake DA, et al. Use of a Patient Hand Hygiene Protocol to Reduce Hospital-Acquired Infections and Improve Nurses' Hand Washing. American Journal of Critical Care. 2015; 24(3): 216 224. PMid:25934718 https ://doi.org/10.4037/ajcc2015898

[14] Mori C. A-Voiding Catastrophe: Implementing a Nurse-Driven Protocol. MEDSURG Nursing. 2014; 23(1): 15-28.

[15] Izzo I, Lania D, Bellea D, et al. Catheter-associated urinary tract infection (CA-UTI) incidence in an Internal Medicine Ward of a Northern Italian Hospital. Le Infezioni in Medicina. 2015.

[16] Al-Qas Hanna F, Sambirska 0, Iyer S, et al. Clinician practice and the National Healthcare Safety Network definition for the diagnosis of catheter-associated urinary tract infection American Journal of lnfection Control. 2013; 41(12): 1173-1177.

[17] Lam T, Omar M, Fisher E, et al. Types of indwelling urethral catheters for short-term catheterisation in hospitalised adults. Cochrane Database Syst Rev. 2014; 9: CD004013. https://doi.org/10 .1002/14651858. CD004013.pub4

[18] Lusardi G, Lipp A, Shaw C. Antibiotic prophylaxis for short-term catheter bladder drainage in adults. Cochrane Database Syst Rev. 2013. https://doi.org/10.1002/14651858.CD005428.pub2

[19] Rosenthal VD, et al. International Nosocomial Infection Control Consortium (INICC) Report, Data Summary of 43 Countries for 2007-2012. Device-associated Module. American Journal of Infection Control. 2014; 42(9): 942-956.

[20] Parry MF, Grant B, Sestovic M. Successful reduction in catheterassociated urinary tract infections: focus on nurse-directed catheter removal. American Journal of Infection Control. 2013; 41(12): 11781181. PMid:23768439 https://doi.org/10.1016/j.ajic. 201 3.03. 296

[21] Davis KF, et al. Reducing Catheter-associated Urinary Tract Infections: A Quality Improvement Initiative. Pediatrics. 2014; 134(3): e857-e864.

[22] Navoa-Ng JA, et al. Device-associated Infections Rates in Adult, Pediatric, And Neonatal Intensive Care Units of Hospitals in the Philippines: International Nosocomial Infection Control Consortium (INICC) findings. American Journal of Infection Control. 2011; 39(7): 548-554. 